УДК 342.56(477).0014.73

\author{
С. В. Ківалов, Ю.Є. Полянський, В. В. Долежан,
} Н. М. Бакаянова, О. Г. Свида

\title{
РЕФОРМУВАННЯ СУДОВОЇ ВЛАДИ ТА СУМІЖНИХ інСТИТУТї В УКРАїні
}

\section{1. Конституційно-правове реформування судової влади}

Відповідно до ч. 1 ст. 6 чинної Конституції України державна влада в Україні, як і в інших демократичних країнах Європи, здійснюється на основі іiі поділу на законодавчу, виконавчу і судову. Всі суди держави здійснюють свої повноваження у встановлених Конституцією межах і відповідно до законів України.

Термін «судова влада» не фігурує в назві розділу VIII Основного Закону. Відсутнє визначення судової влади також у чинному Законі України «Про судоустрій і статус суддів» [1]. Суть судової влади розкривається законодавцем через визначення її функцій. Так, у ч. 1 ст. 8 зазначеного Закону встановлюється, що «суди загальної юрисдикції спеціалізуються на розгляді цивільних, кримінальних, господарських, адміністративних справ і справ про адміністративні правопорушення».

Слід погодитись з думкою авторів, які вважають, що судова влада, 3 одного боку, являє собою систему владних повноважень зі здійснення судочинства, а з іншого - сукупність судів і суддів, які діють у державі. В останньому, вузькому, розумінні судова влада ототожнюються з судовою системою, тобто з системою судових органів, в яких працюють професійні судді [2].

У демократичному суспільстві призначенням судової влади $€$ розгляд різноманітних конфліктів на грунті реалізації права. Наявність таких конфліктів обумовлена недосконалістю людської природи, складністю і різноманітністю суспільних відносин. Будучи незалежною від інших гілок влади, судова влада здійснює судовий контроль закон-

Ківалов С. В., Полянський Ю. Є., Долежан В. В.,

Бакаянова Н. М., Свида О. Г., 2015 
ності їх рішень і дій. Здатність органів судової влади визнавати неконституційними, незаконними і нечинними акти і дії органів державної влади та місцевого самоврядування дозволяє ефективно виявляти свавілля чиновництва стосовно громадян. Будучи державними органами, суди, тим не менш, виступають в ролі арбітрів між органами влади та іншими юридичними і фізичними особами. Проте в окремих колах ще зберігається погляд на суддів як на звичайних представників державного апарату, без урахування їх особливого суспільного і державного статусу.

Останні роки приводом для дискусії щодо статусу суддів стала активізація суспільної критики на адресу тих суддів, які порушують свої державні обов'язки, права і свободи громадян, припускаються тяганини при розгляді справ, вчиняють корупційні правопорушення, збагачуються за рахунок нетрудових доходів.

У зв'язку з цим за порівняно короткий строк було видано декілька законодавчих актів, спрямованих на оздоровлення кадрів професійних суддів, зокрема: «Про відновлення довіри до судової влади в Україні» від 8 квітня 2014 року [3], «Про очищення влади» від 16 вересня 2014 року [4], «Про забезпечення права на справедливий суд» від 12 лютого 2015 року [5].

Президент України Петро Порошенко підкреслив важливість змін у підходах до судової реформи, адже запровадження справедливого судочинства - питання, яке турбує кожного громадянина України. «Справедливий суд - це особливо відчутне питання, адже справедливість стосується кожного громадянина України, кожного з нас, і суд - саме те місце, де кожний 3 нас шукатиме іiі і боротиметься», - сказав Президент на зустрічі зі студентами і викладачами Київського національного університету імені Тараса Шевченка [6].

Слід відзначити, що прийняті у 2014-2015 роках закони щодо оздоровлення судової влади містили додаткові заходи, спрямовані на прискорення виявлення серед професійних суддів осіб, стосовно яких $€$ сумніви: щодо їх доброчесності, зокрема, при обмеженні прав громадян на проведення зборів, мітингів, походів в Україні в період починаючи 3 21 листопада 2013 року, щодо їх причетності до незаконного притягнення громадян до кримінальної відповідальності і накладення адміністративних стягнень, надання дозволів на проведення слідчих (розшукових) дій стосовно учасників акцій протесту. Виявлення таких фактів покладалося на Тимчасову спеціальну комісію при Вищій раді юстиції, висновок якої був підставою для розгляду Вищою радою юстиції питання про порушення суддями присяги.

Закон України «Про очищення влади» (Закон про люстрацію) був поширений на членів Вищої ради юстиції, членів Вищої кваліфікаційної комісії суддів України, професійних суддів, Голову державної судової адміністрації України, його першого заступника та заступника. Відтак спрощений порядок звільнення суддів поширювався на ситуації, коли до 
них не було жодних претензій щодо виконання професійних обов'язків, а підставою для звільнення служило лише перебування на певних посадах (ч. 2 ст. 2 цього Закону).

Посилено мусувалася теза, що практично всі громадяни України не довіряють суддям. Достатніх аргументів на іï підтвердження не наведено. Адже очевидно, що у громадян, які, наприклад, виступали в ролі позивачів та відповідачів по справах, ставлення до суддів залежало від результатів їх розгляду, а переважна більшість громадян або не були учасниками процесів, або особисто не були на них присутні. Головним джерелом інформації про діяльність суддів, мотиви, якими вони керувались при винесенні рішень, служили матеріали засобів масової інформації, часто далекі від об'єктивності.

Очевидно, є доцільним розробити спеціальні наукові рекомендації $з$ дослідження цих питань, щоб можна було скласти об'єктивну думку щодо доброчесності суддів як зараз, так і в майбутньому.

Не можна не звернути уваги на те, що близько року тому Верховний Суд України - найвищий орган у системі судів загальної юрисдикції, звернувся до Конституційного Суду України з клопотанням визнати такими, що не відповідають Конституції України, положення п. 6 ч. 1, п. 2, 13 ч. 3 ст. 3 Закону України «Про очищення влади» щодо заборони певним особам займати певні посади. Суб'єкт права на конституційне подання обгрунтував його порушенням принципу індивідуальної відповідальності при проведенні люстраційних заходів.

До цього часу Конституційний Суд не ухвалив рішення з цього питання [7].

В результаті прийняття у 1996 році чинної Конституції України були внесені істотні зміни до законодавства про судову систему і статус суддів, а також створено Конституційний Суд України та Вищу раду юстиції. Велику роль у цих процесах відіграли Концепція судово-правової реформи 1992 року і так звана «Мала судова реформа» 20012002 років.

Поступово запроваджувалася спеціалізація судів за рахунок створення господарських та адміністративних судів, а також запровадження третейського порядку розгляду цивільних та господарських спорів.

Водночас на деяких етапах реформування судової влади справила негативний вплив політизація цих процесів. Це особливо проявилось в ході розробки проекту Закону України «Про судоустрій і статус суддів», прийнятого у первинній редакції 7 липня 2010 року [8].

Враховуючи цей негативний досвід і потребу уникнути зайвих ускладнень у процесі подальшого вдосконалення законодавства, варто знову звернутись до положень Конституції України і спробувати уточнити або по-новому вирішити важливі теоретичні і практичні питання судівництва, зробити нову спробу ще раз вдосконалити окремі положення Основного Закону, а уже після цього - внести зміни і доповнення до чинного законодавства про судоустрій і статус суддів. 
3 ініціативи Президента України було створено Конституційну комісію для підготовки проекту змін до Конституції України, яка розробила відповідні пропозиції, з приводу яких 26 жовтня 2015 року Венеціанська комісія надала цілком позитивний висновок, що має, очевидно, спростити проходження законопроекту через український парламент.

Окремі законодавчі пропозиції стосуються принципових питань, і їх врахування допоможе принципово по-новому, значно ефективніше вирішити назрілі проблеми.

Враховуючи ускладнення криміногенної ситуації в суддівському співтоваристві, законопроект значно скорочує обсяги так званого суддівського імунітету. Надання згоди на притягнення судді до кримінальної відповідальності віднесено до компетенції Вищої ради правосуддя - в сучасній редакції, Вищої ради юстиції. Без згоди Вищої ради правосуддя суддю не можна буде затримувати або тримати під вартою до винесення обвинувального вироку судом, за винятком затримання судді під час або відразу ж після скоєння тяжкого або особливо тяжкого злочину (ч. 3 ст. 126). Наголошено, що суддю не можна буде притягнути до відповідальності за ухвалене ним судове рішення, за винятком скоєння злочину або вчинення дисциплінарного проступку (ч. 3 ст. 126). Очевидно, неможливість притягнення судді до відповідальності за постановлене ним рішення має виключатись, якщо це рішення залишено без змін судовими інстанціями вищого рівня.

Усувається дисциплінарна відповідальність суддів за порушення присяги, а натомість пропонується встановити стягнення у вигляді звільнення з посади «за вчинення істотного дисциплінарного проступку чи систематичне нехтування своїми обов'язками». Остання підстава також не $є$ досить конкретною, проте, у всякому разі, прийнятнішою, ніж «порушення присяги». У процесі досить глибокої і повної перевірки завжди можна буде знайти об'єктивне рішення з цього питання. Крім того, запропонована норма проекту передбачає і таку підставу для звільнення судді, як «явна невідповідність займаній посаді». Розтлумачити зміст цієї норми значно важче, оскільки вона може бути і не пов'язана з протиправною поведінкою судді, а стосується його особистих якостей, які з тих чи інших причин не були помічені під час кваліфікаційних іспитів і конкурсного добору.

Позитивною рисою проекту є те, що він практично зберіг у недоторканності систему судів загальної юрисдикції. Відповідно до ст. 125 Верховний Суд України визнається найвищим судом у системі судоустрою України і поряд з ним відповідно до закону можуть діяти вищі спеціалізовані суди. Особливо виділено призначення адміністративних судів «з метою захисту прав, свобод та інтересів особи у сфері публічно-правових відносин». При цьому, очевидно, під «особою» тут можна розуміти не лише фізичних, але й юридичних осіб.

Таким чином, проект, розроблений Конституційною комісією і схвалений главою держави, не вніс істотних коректив до структури судової системи 
України. Натомість альтернативний урядовий проект судової реформи виходить зі збереження в Україні лише апеляційних і місцевих судів, а функції касаційної інстанції пропонується покласти на Верховний Суд 3 одночасною ліквідацією всіх існуючих вищих спеціалізованих судів [9].

Для цього, на наш погляд, немає достатніх підстав, оскільки головною місією Верховного Суду відповідно до ч. 6 ст. 2 Закону «Про судоустрій і статус суддів» $€$ забезпечення однакового застосування норм права судами різних спеціалізацій в порядку та спосіб, визначені процесуальним законом, в тому числі шляхом перегляду за наявності підстав окремих судових рішень. Зауважимо, що в деяких великих країнах Європи (Німеччина, Франція тощо) створюються спеціальні судові склади для перегляду судових рішень за наявності суперечностей між вищими судами окремих судових юрисдикцій.

У ч. 3 ст. 125 проекту, нарешті, з'явилась норма, відповідно до якої суд утворюється і ліквідується законом, проект якого вносить до Верховної Ради України Президент України після консультацій з Вищою радою правосуддя, тоді як чинна редакція ст. 125 Конституції цього питання не вирішує, а відповідно до ч. 1 ст. 19 Закону «Про судоустрій і статус суддів» суди загальної юрисдикції утворюються, в тому числі шляхом реорганізації, та ліквідуються Президентом України на підставі пропозицій Державної судової адміністрації України. Венеціанська комісія досить довго наполягала на зміні цього порядку з огляду на небезпеку його політизації Президентом України, і зараз ï позиція підтримана Конституційною комісією.

Відповідно до ч. 4 ст. 129 Конституції у редакції проекту «для суддів спеціалізованих судів відповідно до закону можуть бути встановлені інші вимоги щодо освіти і стажу роботи». Очевидно, йдеться про додаткові умови для здобуття не лише юридичної, але й іншої освіти і застосування в суді знань, одержаних в інших сферах діяльності. Можна при цьому вітати вилучення з тексту чинної норми дискримінаційного положення про те, «що ці судді відправляють правосуддя лише у складі колегій суддів».

Досить істотні зміни і доповнення спроектовані стосовно статусу Вищої ради юстиції або Вищої ради правосуддя, як її пропонується називати надалі:

Відповідно до ч. 1 ст. 131 проекту Рада:

«1) вносить подання про призначення судді на посаду;

2) ухвалює рішення щодо порушення суддею чи прокурором вимог щодо несумісності;

3) розглядає скарги відповідного органу про притягнення до дисциплінарної відповідальності судді чи прокурора;

4) ухвалює рішення про звільнення судді $з$ посади;

5) надає згоду на затримання судді чи тримання його під вартою;

6) ухвалює рішення про тимчасове відсторонення судді від здійснення судочинства; 
7) вживає заходів щодо забезпечення незалежності судді (тут слід було б додати: «на підставі та у спосіб, визначені законом»);

8) ухвалює рішення про переведення суддів з одного суду до іншого;

9) здійснює інші повноваження, визначені Конституцією та законами України».

При цьому повноваження, передбачені пунктами 5-8, в оновленій Конституції фігуруватимуть уперше.

Як в нинішньому, так і в оновленому вигляді Рада не $є$ частиною судової влади, оскільки не розглядає судових справ, проте вона наділена досить серйозними юрисдикційними повноваженнями щодо суддів. За своїм призначенням вона обслуговує потреби судової влади і по суті входить до їі інфраструктури [10].

За своїм змістом нові положення Конституції щодо Вищої ради правосуддя істотно наближають цей колегіальний орган до європейських зразків. Насамперед, це стосуються виконання побажань Венеціанської комісії щодо обов'язковості членства в ній щонайменше половини членів з числа суддів, обраних самими суддями.

Відповідно до п. 4.2 ст. 131 проекту Рада формується з двадцяти одного члена, з яких десятьох обирає з'їзд суддів України з числа суддів чи суддів у відставці; двох - призначає Президент України; двох обирає Верховна Рада України, двох - обирає з’їзд адвокатів України, двох - обирає всеукраїнська конференція прокурорів, двох - обирає з'їзд представників вищих юридичних навчальних закладів та наукових установ з числа науковців-правників.

Таке формування Ради дозволяє залучити до іï роботи якомога більше представників різних юридичних професій. При цьому Голова Верховного Суду України входитиме до складу Ради за посадою, тобто залишення ним цієї посади виключає подальше членство в Раді. Решта членів Ради зможуть обіймати посади членів Ради лише два строки поспіль.

Вища рада правосуддя набуває повноважень за умови обрання та/ або призначення щонайменше п'ятнадцяти іï членів, серед яких, очевидно, пропорційну більшість також мають становити судді.

Конституційний Суд України за своєю компетенцією являє собою орган конституційного контролю і посідає особливе місце поза системою судів загальної юрисдикції.

Відповідно до ст. 147 проекту Конституційний Суд України вирішує питання про відповідність законів та інших нормативних актів Конституції України і здійснює офіційне тлумачення Конституції України, а також інші повноваження відповідно до Конституції. Таким чином 3 Конституційного Суду знімається обов'язок тлумачити закони України, що сприятиме кращому упорядкуванню його діяльності.

Статтею 149-1 проекту передбачено підстави припинення повноважень судді Конституційного Суду, які в основному збігаються з підставами припинення повноважень суддів судів загальної юрисдикції. 
Принципово новим повноваженням Конституційного Суду відповідно до ст. 131-1 проекту $є$ надання йому права вирішувати питання про відповідність Закону України Конституції України за конституційною скаргою особи, яка вважає, що застосований при ухваленні остаточного судового рішення Закон України суперечить Конституції України. Конституційна скарга може бути подана у разі, якщо вичерпано всі національні засоби юридичного захисту.

Схвально оцінюючи концепцію і основні положення конституційного проекту, вважаємо за необхідне звернути увагу на окремі спірні положення і неточності, які містяться у цьому документі.

Передусім вважаємо, що запропонована назва розділу VII «Правосуддя»неповністю відображає його зміст. Сучасна наукова доктрина виходить $з$ того, що правосуддя - це «...правозастосовна діяльність суду 3 розгляду і вирішення у встановленому законом процесуальному порядку віднесених до його компетенції справ» [11]. Отже, виходячи з того, що відповідно до ст. 6 чинної Конституції державна влада в Україні здійснюється на основі іiї поділу на законодавчу, виконавчу і судову, зазначений розділ слід назвати «Судова влада».

Важко погодитися з віднесенням до юрисдикції Конституційного Суду України «вирішення питання за зверненням Президента України про відповідність Конституції України акта голови громади, ради громади, районної, обласної ради (п. 1-1 ст. 150 Конституції у запропонованій редакції). По-перше, тому що такі органи ще не створені, а зазначені посадові особи ще не призначені. По-друге, для усунення порушень Конституції і законів при виданні актів цими структурами навряд чи потрібно вдаватися до посередництва самого глави держави і Конституційного Суду. Очевидно, що це можна буде зробити за зверненням префекта або представника Президента під іншою назвою безпосередньо до місцевого адміністративного суду.

Зміни і доповнення до Основного Закону - дуже відповідальна справа, і невипадково цей захід повторюється нечасто. Тому слід зробити все належне від представників законодавчої влади, щоб статус судової влади та іiї представників було закріплено в цьому документі бездоганно і не викликав жодних ускладнень при реалізації положень Конституції.

На деякі давні недоречності у чинному тексті Конституції комісія не звернула увагу. Так, неточно сформульовано ч. 4 ст. 124 чинної Конституції, відповідно до якої народ безпосередньо бере участь у здійсненні правосуддя через народних засідателів і присяжних. Адже неможливо уявити собі безпосереднє здійснення судочинства народом, тобто громадою. У зв’язку з цим слід закріпити в Конституції, що правосуддя здійснюється від імені народу його представниками - народними засідателями і присяжними.

Редакцію ч. 2 ст. 126 Основного Закону «Вплив на суддю в будь-який спосіб забороняється» можна запропонувати замінити на таку: «Проти- 
правне втручання в діяльність судді зі здійснення правосуддя, а також прояв неповаги до суду та судді тягнуть за собою відповідальність, встановлену законом».

Можливо, до деяких питань доцільно повернутись перед остаточною доробкою законопроекту, яка передбачає врахування пропозицій комітетів Верховної Ради України і окремих депутатів.

\section{2. Конституційно-правове реформування прокуратури України}

Діяльність прокуратури як однієї з найважливіших державних структур, що сприяє додержанню і зміцненню законності і правопорядку, притягує підвищену увагу громадськості як в Україні, так і за їі межами. Функціонуючи в умовах перманентної кризової ситуації, що склалася у країні, прокуратура закликана властивими їй методами сприяти стабілізації соціально-економічної і політичної обстановки і розвитку України як демократичної правової держави.

Правове регулювання діяльності прокуратури в новітню епоху відзначалося істотними змінами. В результаті судово-правової реформи в Російській імперії 1864 року на прокуратуру було покладено лише підтримання державного обвинувачення в суді та здійснення нагляду за додержанням законів у місцях позбавлення волі. В радянській Україні з 1922 року прокуратура здійснювала нагляд за додержанням законів органами влади на місцях (загальний нагляд) за діяльністю органів досудового розслідування, безпосереднє проведення розслідування, підтримання обвинувачення в суді та нагляд за утриманням ув'язнених. В 1933 році було створено Прокуратуру Союзу РСР, до складу якої увійшла і прокуратура УРСР. В роки посилення тоталітаризму в СРСР прокуратура, беручи активну участь у масових репресіях, по суті перестала бути провідником законності. Певні зрушення на краще наступили після смерті Й. Сталіна. На прокуратуру були покладені загальний нагляд, нагляд за виконанням законів при проведенні попереднього слідства, участь у розгляді справ у судах, нагляд у пенітенціарних установах. Здійснювалися заходи по охороні соціалістичної власності, боротьба зі злочинністю, розслідування по кримінальних справах [12, с. 6-27].

У незалежній Україні правовий статус прокуратури було закріплено Законом України «Про прокуратуру» від 5 листопада 1991 року [13], який став одним з перших законодавчих актів незалежної України. До iii функцій відносились: загальний нагляд, нагляд за додержанням законів органами, що проводять боротьбу зі злочинністю, розслідування злочинних діянь, підтримання обвинувачення в суді, участь у розгляді судами справ усіх категорій, нагляд за додержанням законів у місцях ув'язнення та застосування інших заходів примусового характеру, нагляд у військовій сфері. 
Відповідно до ст. 121 Конституції України, прийнятої у 1996 році, на прокуратуру було покладено представництво інтересів громадянина або держави в суді, нагляд за додержанням законів органами, що здійснювали оперативно-розшукову діяльність, дізнання, досудове слідство, нагляд за додержанням законів при виконанні судових рішень по кримінальних справах, а також при застосуванні інших заходів примусового характеру, пов'язаних з обмеженням особистої свободи громадян.

У 2004 році до цих функцій було додано нагляд за додержанням прав і свобод людини і громадянина, додержанням законів з цих питань органами виконавчої влади, місцевого самоврядування, посадовими і службовими особами.

Остання з цих функцій все ще залишається закріпленою у Конституції України, хоча ії не передбачено чинним Законом України «Про прокуратуру». Крім того, продовжує діяти п. 9 Перехідних положень Конституції України 1996 року, відповідно до якого прокуратура виконує функцію нагляду за додержанням і застосуванням законів (колишній загальний нагляд).

Починаючи з 1995 року, коли Україна, вступаючи до Парламентської асамблеї Ради Європи, дала згоду ліквідувати загальний нагляд, пройшло близько 20 років. ПАРЄ досягла цієї мети, адже суверенна Україна опинилась перед нескінченними нагадуваннями і попередженнями 3 цього приводу. Зараз уже не варто коментувати історію цих подій, а потрібно виходити з реальності. Врешті-решт, у чомусь мають рацію науковці і політики, які вважають, що захоплення прокуратури загальнонаглядовою діяльністю певною мірою послаблювало ії зусилля у протидії злочинності.

До ст.2 нового Закону України «Про прокуратуру»в редакції Закону № 578-8 від 2 липня 2015 року [14] на прокуратуру покладено такі функції:

1) підтримання державного обвинувачення в суді;

2) представництво інтересів громадянина і держави в суді у випадках, визначених цим законом;

3) нагляд за додержанням законів органами, які здійснюють оперативно-розшукову діяльність, дізнання, досудове слідство;

4) нагляд за додержанням законів при виконанні судових рішень по кримінальних справах, а також при застосуванні інших заходів примусового характеру, пов'язаних 3 обмеженням особистої свободи громадян.

На наш погляд, і в нормі Конституції, і в Законі «Про прокуратуру» доцільно поміняти місцями пункти перший і третій, оскільки нагляд прокурора за додержанням законів під час досудового розслідування (процесуальне керівництво розслідуванням) на практиці відбувається раніше, ніж підтримання державного обвинувачення в суді.

Пункт 3 ст. 3 Закону «Про прокуратуру» слід викласти у такій редакції: «Нагляд за додержанням законів у досудовому кримінальному 
провадженні», а в п. 4 словосполучення «особистої свободи громадян» замінити на «особистої свободи» з огляду на те, що ця норма поширюється як на громадян України, так і на громадян інших держав і осіб без громадянства.

Повноваження прокурора при здійсненні нагляду за додержанням законів у формі процесуального керівництва, визначені у ч. 2 ст. 36 ҚПК України, носять переважно владно-розпорядчий характер, тобто прокурор або сам усуває порушення закону в процесі розслідування, або пред’являє відповідні вимоги органам розслідування, які підлягають обов'язковому виконанню, чи вирішує деякі процесуальні питання, звертаючись до слідчого судді.

Прокурор здійснює координацію діяльності правоохоронних органів по боротьбі із злочинністю та іншими правопорушеннями.

Підтримання прокурором державного обвинувачення в суді $є$ підсумком його попередньої діяльності на стадії досудового розслідування в ролі процесуального керівника. Відповідно до ч. 3 ст. 35 ҚПК України участь прокурора в суді $є$ обов'язковою, крім випадків, передбачених законом. Відповідно до ст. 22 чинного Закону «Про прокуратуру» прокурор підтримує державне обвинувачення в суді стосовно кримінальних правопорушень, користуючись при цьому правами і виконуючи обов'язки, передбачені КПК України. За потреби керівником прокуратури призначається група державних обвинувачів з урахуванням складності кримінального провадження.

Під час судового розгляду прокурор має право висунути додаткове обвинувачення, змінити обвинувачення, якщо неупереджений судовий розгляд не підтверджує вини обвинуваченого. На жаль, в сучасній Україні прокурори рідко відмовляються від обвинувачення навіть за наявності безспірних підстав для цього, а відтак сприяють безпідставному засудженню громадян, права яких часто поновлюються лише Європейським судом з прав людини.

За наявності передбачених законом умов державний обвинувач може укласти з підозрюваним або обвинуваченим угоду про визнання вини, що спрощує кримінальне провадження і може полегшити долю особи, яка вчинила кримінальне правопорушення. Суд затверджує угоду, в тому числі стосовно погоджених сторонами умов визначення покарання. Такий підхід до підтримання державного обвинувачення виправдав себе в прокуратурах і судах США і низки європейських країн.

Чинною Конституцією України (п. 2 ст. 12) на прокуратуру покладено представництво інтересів громадян або держави в суді, хоча прокурори i до цього в масовому порядку пред'являли позиви у суди в інтересах як держави, так і громадян.

У Законі «Про прокуратуру» встановлено всього дві підстави, коли прокурор може використати свої повноваження для захисту інтересів громадянина в суді: а) неповноліття особи; б) недієздатність або обмежена дієздатність, коли законні представники або органи держави, наді- 
лені відповідними повноваженнями, не здійснюють або неналежно здійснюють захист особи. Такі обставини, як літній вік, фізичний стан, інвалідність, зараз не враховуються. Автори нової редакції Закону не врахували навіть обставин, що склалися в результаті бойових дій на Донбасі, коли значно розширився контингент людей, що претендують на медичну і юридичну допомогу з боку держави, яку вони захищали.

Проте виявляється, що можна піти ще далі. Автори законопроекту про внесення змін до Конституції України, про який йшлося у попередньому розділі, взагалі виключили участь прокурора у судовому представництві інтересів будь-кого з фізичних осіб. У ст. 131-1 проекту змін до Конституції України йдеться лише про представництво інтересів держави в суді у виключних випадках і у порядку, що визначені законом.

Відповідно до ч. 3 ст. 23 чинного Закону «Про прокуратуру» прокурор здійснює в суді представництво законних інтересів держави у випадку порушення і загрози порушенню інтересів держави, якщо захист цих інтересів не здійснює або неналежним чином здійснює орган державної влади, орган місцевого самоврядування чи інший суб'єкт владних повноважень, до компетенції якого віднесено відповідні повноваження, а також у разі відсутності такого органу.

Слід визнати, що всі інтереси держави $є$ законними, якщо це дійсно державні, а не вузькополітичні або кланові інтереси, а отже; слово «законні» тут навряд чи на місці. Думається, що прокурор зобов'язаний захищати інтереси не лише держави, а й територіальних громад, якщо вони порушуються державними чиновниками, це набуває особливої актуальності при проведенні в Україні адміністративної реформи.

Звертає на себе увагу, що відповідно до ст. 23 Закону «Про прокуратуру» прокурор має звернутись до суду двічі: вперше - для судового підтвердження наявності підстав для судового представництва і вдруге - для розгляду справи по суті. Чим не бюрократизм в його класичному прояві і тим небезпечніший, що він офіційно закріплений в законі? У всякому разі простежується явна зневага до інституту прокуратури і прагнення всіляко загальмувати використання прокурором своїх судовопредставницьких повноважень.

Традиційно, від часів судової реформи і до сучасності, до компетенції прокуратури належав нагляд за додержанням законів органами кримінально-виконавчої системи.

Відповідно до ст. 26 чинного Закону України «Про прокуратуру», прокурор здійснює нагляд за додержанням законів при виконанні судових рішень у кримінальних справах, а також при застосуванні інших заходів примусового характеру, пов'язаних з обмеженням особистої свободи громадян.

Прокурорський нагляд у цій сфері поширюється на місця тримання затриманих, попереднього ув'язнення, установи, в яких засуджені відбувають покарання, установи, де перебувають особи, до яких застосовані 
заходи медичного або виховного характеру, і будь-які інші місця, в які доставлені особи з метою складення протоколів про адміністративні правопорушення або в яких особи примусово тримаються відповідно до судового рішення або рішення адміністративного органу.

Значущість прокурорського нагляду у цій сфері не викликає сумнівів через те, що інших незалежних органів соціального контролю тут практично не існує, а відомчий контроль далеко не завжди $€$ достатньо ефективним. Навіть в умовах постійного прокурорського нагляду у виправних установах періодично виникають ексцеси у зв'язку з масовими непокорами адміністрації, протестними акціями і навіть бунтами 3 людськими жертвами. Можна собі уявити, якого розмаху ці явища набули б в умовах відсутності прокурорського нагляду.

Відповідно до ч. 1 ст. 26 Закону «Про прокуратуру» прокурор при здійсненні нагляду має право:

1) у будь-який час за посвідченням, що підтверджує займану посаду, відвідувати місця тримання затриманих, попереднього ув'язнення, установи, в яких засуджені відбувають покарання, установи, в яких перебувають особи, щодо яких застосовані заходи медичного або виховного характеру, та будь-які інші місця, в яких особи примусово тримаються згідно з судовим рішенням або рішенням адміністративного органу;

2) опитувати осіб, які перебувають у місцях, зазначених у п. 1 цієї статті, з метою отримання інформації про умови їх тримання та поводження з ними, ознайомлюватися з документами, на підставі яких ці особи тримаються в таких місцях або до них застосовано заходи примусового характеру;

3) перевіряти законність наказів, розпоряджень, інших актів відповідних органів та установ, невідповідність законодавству, вимагати від посадових і службових осіб скасування та усунення порушень закону, до яких вони призвели, а також скасовувати незаконні акти індивідуальної дії;

4) вимагати від посадових та службових осіб пояснень щодо допущених порушень, а також усунення порушень та причин і умов, що їм сприяли, притягнення винних до передбаченої законом відповідальності;

5) знайомитися з матеріалами виконавчого провадження щодо виконання судових рішень у кримінальних справах, робити з них виписки, знімати з них копії та в установленому законом порядку оскаржувати рішення, дії та бездіяльність державних виконавців;

6) вимагати від керівників органів вищого рівня проведення перевірок підпорядкованих і підконтрольних органів;

7) звертатися до суду з позовом (заявою) у визначених законом випадках.

Відповідно до ч. 3 цієї статті прокурор зобов'язаний негайно звільнити особу, яка незаконно перебуває в місці застосування заходів примусового характеру.

У конституційному проекті нагляд прокуратури за додержанням законів у цій сфері взагалі не закріплюється, що, на нашу думку, є необ- 
грунтованим, волюнтаристським підходом до регламентації діяльності прокуратури.

Конституційним проектом вирішені деякі питання правового статусу Генерального прокурора України. Відповідно до ч. 3 ст. 131-1 передбачено, що прокуратуру України очолює Генеральний прокурор, якого призначає на посаду та звільняє з посади за згодою Верховної Ради України Президент України.

Проектом не передбачено можливості висловлення Верховною Радою України недовіри Генеральному прокуророві України, що мало наслідком його відставку з посади (ст. 122 чинної Конституції). Це сприятиме зміцненню правового становища Генерального прокурора, допоможе запобігти його усуненню з посади 3 політичних міркувань.

Слід також схвалити продовження строку повноважень Генерального прокурора з п'яти до шести років, можливість продовження їх на такий же строк.

Проте виконання цих вимог Конституції зможе стати реальністю лише за умови забезпечення політичної стабільності в крайні.

Відповідно до ч. 2 ст. 131-1 проекту «організація та порядок діяльності прокуратури визначаються законом». Це, зокрема, стосується організаційних, управлінських і кадрових питань, коли відповідні норми уже застосовувались упродовж 2014-2015 років. При цьому не піддаються сумніву положення ст. 211 чинної Конституції України і ст. 1 чинного Закону України «Про прокуратуру».

Відповідно до ст. 7 Закону «Про прокуратуру» до системи прокуратури України включено, крім регіональних та місцевих прокуратур, також військові прокуратури та Спеціалізована антикорупційна прокуратура.

Їстотно змінено порядок зайняття посади прокурора із застосуванням конкурсного порядку добору кандидатів на ці посади, причому для поповнення прокурорської системи новими кадрами використовується атестація прокурорів, які вже займають ці посади, і претендентів, які на рівних умовах беруть участь у конкурсах на вакантні посади.

3 підстав, передбачених Законом України «Про очищення влади» від 16 вересня 2014 року, здійснюється люстрація прокурорських кадрів.

Значну роль в організаційному забезпеченні органів прокуратури почали відігравати органи прокурорського самоврядування, а також кваліфікаційно-дисциплінарні комісії прокуратури; вдосконалено підстави та порядок притягнення прокурорів до дисциплінарної відповідальності. Чіткіше, ніж раніше, здійснено розподіл повноважень між керівниками прокуратур і прокурорами відповідних прокуратур.

На черзі - вирішення складних організаційних питань створення нової системи місцевих прокуратур з урахуванням нового адміністративно-територіального поділу, зокрема, створення відділень місцевих прокуратур у колишніх районних центрах. 
Потрібно також чітко вирішити питання або про право всіх прокурорів на класні чини незалежно від того, коли вони були присвоєні, або про відсутність такого права.

Думається, що передчасно робити якісь категоричні висновки щодо зазначених та інших питань організації та діяльності прокуратури. Найкращим критерієм для цього має стати практика застосування зазначених положень Конституції України і чинного законодавства.

\section{3. Конституційно-правове регулювання адвокатури}

Комплексний підхід до оновлення суспільного життя не означає відкидання найкращих традицій та здобутків минулого, адже полягає в усуванні непрацюючих механізмів, неефективних форм взаємодії, законодавчих прогалин та виправленні помилок. Зазначене в повній мірі стосується й реформи адвокатури.

Стратегія реформування судоустрою, судочинства та суміжних правових інститутів на 2015-2020 роки, яку схвалено Указом Президента України від 20 травня 2015 року № 276/2015 (далі - Стратегія), констатувала невідповідність формального статусу адвоката фактичним умовам здійснення адвокатської діяльності, в тому числі недосконалість практичного забезпечення прав адвоката і гарантій адвокатської діяльності; недосконалу систему формування органів адвокатського самоврядування та їх взаємодії, гарантій незалежності та належного виконання ними своїх функцій; недостатній рівень професійної підготовки адвокатів; неефективність дисциплінарного контролю і етичних стандартів в адвокатській діяльності; відсутність комплексного підходу та збалансованості у розподілі повноважень у системі надання безоплатної правової допомоги; недосконалість бюджетного і фінансового управління в системі адвокатського самоврядування.

Проблеми сучасної української адвокатури, безумовно, пов'язані із проблемами українського суспільства в цілому. Реформа адвокатури має провадитися одночасно з реформуванням судоустрою, прокуратури та інших правоохоронних органів.

Визначення видів правової допомоги, які можуть здійснюватися лише адвокатом, $є$ одним з головних напрямків підвищення рівня надання кваліфікованої правової допомоги, забезпечення її доступності, посилення ролі адвокатури в суспільстві та адвоката у судовому процесі.

Зміни до Конституції України, запропоновані проектом Робочої групи з питань правосуддя та суміжних інститутів Конституційної комісії, створеної Указом Президента України від 3 березня 2015 року № 119, у ч. 2 ст. 131 передбачають здійснення захисту та представництва в судах саме адвокатурою. Такі зміни покликані забезпечити підвищення якості надання правової допомоги та якості здійснення правосуддя 
в цілому, не обмежуючи при цьому учасників судового процесу у праві на доступ до правосуддя.

Впровадження зазначеного положення $€$ не лише питанням адвокатури, адже стосується суспільства в цілому, реалізації конституційного права громадян та організацій на отримання кваліфікованої правової допомоги.

Кваліфікована правова допомога надається незалежним адвокатом, який має особливий статус. Особливості цього статусу отримають свій вираз, починаючи з процедури його здобуття, реалізуються при здійсненні адвокатом його повноважень, обранні організаційної форми діяльності, участі в адвокатському самоврядуванні, дотриманні Правил адвокатської етики, збереженні адвокатської таємниці, особливому порядку притягнення до відповідальності та інших гарантіях адвокатської діяльності.

У проекті змін до Конституції України привертає на себе увагу використання нового для українського законодавства терміна «правнича допомога».

Чинна редакція Конституції України (ч. 1 ст. 59) та діюче законодавство України, у тому числі закони України «Про адвокатуру та адвокатську діяльність», «Про безоплатну правову допомогу», процесуальне законодавство містять термін «правова допомога». На практиці широко використовується й термін «юридична допомога».

Правова (юридична) допомога традиційно розглядається як державна, недержавна (приватна, комерційна) діяльність професійних юристів з надання кваліфікованої допомоги фізичним та юридичним особам у розумінні, правильному застосуванні та дотриманні законодавства, консультації з юридичних питань та питань права, що спрямована на захист та сприяє дотриманню прав і законних інтересів громадян [15].

Можна погодитися із таким визначенням терміна «юридична допомога», проте правову допомогу не слід сприймати як тотожне їй поняття. За Законом України «Про безоплатну правову допомогу» правова допомога - це надання правових послуг, спрямованих на забезпечення реалізації прав і свобод людини і громадянина, захисту цих прав і свобод, їх відновлення у разі порушення (п. 3 ч. 1 ст. 1 Закону), а суб'єктами надання первинної правової допомоги є: органи виконавчої влади; органи місцевого самоврядування; фізичні та юридичні особи приватного права; спеціалізовані установи (ч. 1 ст. 9 Закону).

Порівнюючи поняття «правова допомога» та «правнича допомога», слід акцентувати увагу на тому, що у першому випадку йдеться про отримання допомоги 3 правових питань, а у другому - про отримання такої допомоги від спеціального суб'єкта - правника.

В юридичній літературі зазначалося, що «правник - це фахівець, який не лише має юридичну освіту, а, насамперед, $є$ представником певної частини інтелектуальної еліти суспільства, покликаний виконувати місію надання правової допомоги як кожній окремій людині, так 
і людським спільнотам: громадським об'єднанням і трудовим колективам, тобто суспільству в усіх сферах його життєдіяльності» [16, с. 29].

Таким чином, під правником розуміють фахівця у галузі права, тобто юриста, яким є як адвокат, так й інші особи: прокурори, нотаріуси, юрисконсульти, судді.

Використання зазначеного терміна у проекті змін до Конституції України сприймається неоднозначно. Фактично термін «правнича допомога» $€$ неточним, адже передбачає ширше коло суб'єктів надання правової допомоги, ніж той, що мається на увазі. Якщо захист та представництво як види допомоги в суді здійснюються лише адвокатами (ч. 2 ст. 131 проекту), то має використовуватися термін «допомога адвоката».

Як зазначає С. Сафулько, «у ряді конституцій хоч і не вказується, що правова допомога забезпечується адвокатами, але це само собою розуміється через традиції суспільного ладу цих країн, і там це питання не виникає. За будь-яких обставин у проаналізованих нами конституціях і основних конституційних актах більш як 60 країн світу ми не знаходимо будь-якої згадки, крім адвокатів, на яких покладається правова допомога (захист, представництво), ще і про «фахівців у галузі права» [17, с. 135].

У будь-якому випадку термін «правова допомога» хоча й $є$ більш узагальнюючим, але не таким помилковим у сприйнятті того, хто саме $€$ суб'єктом надання правової допомоги в суді. Термін же «допомога адвоката» $€$ найбільш коректним з точки зору здійснення захисту та представництва у судовому процесі.

Безоплатна правова допомога $є$ видом правової допомоги та важливим міжнародним стандартом захисту прав та свобод людини. Реформування інституту безоплатної правової допомоги має здійснюватися у напрямку спрощення доступу громадян до безоплатної правової допомоги через удосконалення стандартів якості іiї надання та їх дотримання; розширення можливості надання первинної та вторинної безоплатної правової допомоги у цивільних та адміністративних справах, у тому числі у регіонах, на більш високому рівні; забезпечення належного фінансування системи надання безоплатної правової допомоги як з державного бюджету, так і з приватних джерел.

Система безоплатної правової допомоги має бути такою, аби, попри iii управління і фінансування державою, вона залишалася незалежною від держави; за інших обставин у випадку конфлікту між інтересами громадянина та інтересами держави захист інтересів громадянина може опинитись під загрозою [18, с. 12].

До ключових проблем юридичної спільноти слід віднести й вирішення питання про подальшу діяльність юристів-підприємців, які на сучасному етапі діють поряд з адвокатами в судах. У світлі проекту змін до Конституції необхідно ретельно продумати механізм вступу до адвокатури практикуючих юристів. 
Зарубіжний досвід свідчить про різні варіанти об'єднання юридичних професій; це, безумовно, - складний процес, який потребує визначення певних етапів та розробки заходів впровадження змін до законодавства.

У Франції реформа з об'єднання юридичних професій тривала майже 40 років. На першому етапі реформ у 1971-1972 роках були об'єднані професії повіреного при судах вищих інстанцій та консультанта-експерта в комерційних судах з професією адвоката [19]. Другий етап розпочався з 1 січня 1992 року, адже до цього часу адвокати, об'єднані у колегії, працювали окремо від представників ще однієї юридичної професії - юридичних консультантів [20; 21]. В результаті реформи юрисконсульти отримали можливість набути статусу членів адвокатських колегій, а до переліку видів адвокатської діяльності увійшли функції, які раніше були притаманні тільки професії юрисконсульта. Так, адвокати мають право створювати товариства комерційного типу, ставати членами об'єднань економічного стимулювання, які покликані сприяти економічній діяльності своїх членів. Третій етап реформ, який було розпочато в 2009 році та впроваджено з 1 січня 2012 року, завершив об'єднання юридичних професій, коли міністерство судових представників увійшло до інституту адвокатури [22;23].

У Республіці Білорусь при впровадженні монополії адвокатів на судове представництво на підставі Закону Республіки Білорусь від 30 грудня 2011 року № 334-3 «Про адвокатуру та адвокатську діяльність в Республіці Білорусь» за представниками юридичного консалтингу було збережено право після набуття статусу адвоката залишитися засновниками юридичних фірм, які вони очолювали до вступу в адвокатуру [24].

Монополія адвокатури на здійснення захисту та представництва, надання консультацій правового характеру діє також в Люксембурзі, І̇спанії, Португалії, Норвегії, Греції, Кіпрі, Республіці Корея, Гонконзі, Тайвані.

Саме встановлення єдиних стандартів до діяльності захисників та представників може забезпечити довіру до юридичної професії, а підвищення ролі інституту адвокатури є логічним етапом еволюції правової системи.

У питанні забезпечення належної професійної діяльності адвокатури, управління юридичними професіями та представництва колективних інтересів адвокатів провідна роль належить Національній асоціації адвокатів України у відповідності до ії статутних завдань.

Новий вектор розвитку адвокатури передбачає зміцнення на інституційному рівні Національної асоціації адвокатів України, забезпечення балансу повноважень органів адвокатського самоврядування, у тому числі кваліфікаційно-дисциплінарних комісій адвокатури; удосконалення системи підзвітності органів адвокатського самоврядування, посилення відповідальності їх членів. Підвищення вимог до здійснення адвокатської діяльності, зокрема, посилення професійних та морально-етичних вимог до осіб, які мають намір отримати статус адвоката, удосконалення по- 
рядку підвищення кваліфікації адвокатів та дисциплінарного контролю $є$ важливою гарантією здійснення адвокатурою своїх функцій.

Запропоновані зміни до Конституції України мають стати поштовхом для подальших реформ, які мають включати удосконалення правового регулювання професійних прав та обов'язків адвокатів, соціально-економічних, фінансових та оперативних умов здійснення правової діяльності завдяки впровадженню системи страхування професійної цивільної відповідальності адвокатів, надання адвокатам права застосовувати спрощену систему оподаткування, обліку та звітності. Ефективність гарантій здійснення адвокатської діяльності обумовлює також впровадження ефективних механізмів притягнення до відповідальності посадових осіб за порушення гарантій незалежності адвокатів та посилення гарантій захисту адвокатської таємниці.

\section{Л і те р а т р а}

1. Про судоустрій і статус суддів : Закон України від 7 лип. 2010 р. № 2453-VI // Відомості Верховної Ради України. - 2015. - № 18, 19-20. - Ст. 132.

2. Грошевой Ю. М. Законодательство о судоустройстве Украины и проблемы его кодификации / Ю.М. Грошевой // Правова система України: теорія і практика: матеріали наук.-практ. конф. - К., 1993. - С. 376.

3. Про відновлення довіри до судової влади в Україні : Закон України від 8 квіт. 2014 р. № 1188-VII // Відомості Верховної Ради України. - 2014. - № 23. - Ст. 870.

4. Про очищення влади: Закон України від 16 верес. 2014 р. № 682-VII // Відомості Верховної Ради України. - 2014. - № 44. - Ст. 2041.

5. Про забезпечення права на справедливий суд : Закон України від 4 черв. 2015 р., підстава 469-19 // Відомості Верховної Ради України. - 2015. — № 18, 19-20. Ст. 132.

6. Президент про реформу системи правосуддя: Людям немає де шукати справедливості. Ми з вами разом мусимо це змінити [Електронний ресурс] : [зустріч Президента зі студентами та викладачами КНУ ім. Т. Г. Шевченка 6 листоп. 2015 р.] // Офіційний сайт Президента України. - Режим доступу: http://www.president.gov.ua/ news/prezident-proreformu-sistemi-pravosuddya-lyudyam-nemaye-de-36260.

7. КСУ оголосив перерву в «очищенні влади» // Юридична газета. - 2015. - № 43. - C. 1,2 .

8. Про судоустрій і статус суддів: Закон України від 7 лип. 2010 № 2453-VI // Відомості Верховної Ради. - 2010. - № 41-42, 43, 44-45. - Ст. 529.

9. Арсеній Яценюк вирішив підмінити собою Конституційну комісію [Електронний ресурс]. - Режим доступу: http://ukr.lb.ua/news/2015/10/21/ 318906_kabmin_zaproponuvav_alternativu.html.

10. Судоустрій України : підручник / С. В. Ківалов, Ю. Є. Полянський, М. В. Косюта, В. В. Долежан; за ред. С. В. Ківалова; рец.: О. П. Подцерковний [та ін.]; НУ ОЮА. - K.: Юрінком Їнтер, 2011. - 385 с.

11. Правосуддя / В. T. Макаренко // Юридична енциклопедія. - К., 2008. - Т. 5. C. $50-51$.

12. Прокуратура України : навч. посіб. / П. В. Шумський. - К. : Вентурі, 1998. - 336 с.

13. Про прокуратуру : Закон України від 5 листоп. 1991 р. № 1789-XII // Відомості Верховної Ради України. - 1991. - № 53. - Ст. 793.

14. Про прокуратуру : Закон України від 14 жовт. 2014 р. № 1697-VII // Відомості Верховної Ради України. - 2015. - № 2-3. - Ст. 12. 
15. Юридическая помощь [Електронний ресурс] // Большой юридический словарь. 3-е изд., доп. и перераб. / под ред. А. Я. Сухарева. - M. : ИНФРА-М., 2007. Режим доступу: http://slovari.yandex.ru/dict/jurid/article/jur3/jur6866.htm\&stpar1=1.7.1.

16. Сущенко В.М. Модель професійної культури правника: критерії та підходи / В. М. Сущенко // Наукові записки. - Т. 90. Юридичні науки. - С. 29-33.

17. Сафулько С. Українська адвокатура: в очікуванні вчорашнього дня / С. Сафулько // Право України. - 2010. - № 3. - С. 133-139.

18. Бова Є. Ю. Організація безоплатної правової допомоги в Україні : автореф. дис. ... канд. юрид. наук: $12.00 .10 /$ Є. Ю. Бова. - K., 2009. - 20 с.

19. Loi n $71-1130$ du 31 décembre 1971 modifiée portant réforme de certaines professions judiciaires et juridiques [Електронний ресурс]. - Режим доступу: www. legifrance.gouv.fr.

20. Loi n90-1259 du 31 décembre 1990 portant réforme de certaines professions judiciaires et juridiques [Електронний ресурс]. - Режим доступу: www. legifrance.gouv.fr.

21. Décret n91-1197 du 27 novembre 1991 organisant la profession d’avocat [Електронний ресурс]. - Режим доступу: www. legifrance.gouv.fr.

22. Décret n²009-685 du 12 juin 2009 modifiant l'article 43 du décret n 91-1197 du 27 novembre 1991 organisant la profession d'avocat [Електронний ресурс]. - Режим доступу: www. legifrance.gouv.fr.

23. Loi n²011-331 du 28 mars 2011 de modernisation des professions judiciaires ou juridiques et certaines professions réglementées (actes d'avocat) [Електронний ресурс]. - Режим доступу: www. legifrance.gouv.fr.

24. Закон Республики Беларусь от 30 декабря 2011 г. № 334-3 «Об адвокатуре и адвокатской деятельности в Республике Беларусь» [Електронний ресурс]. - Режим доступу: http://www.rka.by/content/zakon-ob-advokature-i-advokatskoy.

\section{А н о т а ці я}

Ківалов С. В., Полянський Ю. Е., Долежан В. В., Бакаянова Н. М., Свида О.Г. Реформування судової влади та суміжних інститутів в Україні. - Стаття.

У статті досліджуються проблеми конституційного і законодавчого регулювання процесів реформування судової влади України та суміжних інститутів. Стаття містить аналіз основних аспектів судової реформи, включаючи зміни до Конституції України в частині правосуддя, та пропонує стратегічний погляд на розвиток судової системи України відповідно до європейських стандартів. Автори висловлюють свої погляди та доходять висновків щодо запропонованих конституційних змін.

Ключові слова: Конституція України, судова влада, прокуратура, адвокатура, судово-правова реформа.

\section{А н но т а ция}

Кивалов С. В., Полянский Ю. Е., Долежан В.В., Бакаянова Н. М., Свида А.Г. Реформирование судебной власти и смежных институтов в Украине. - Статья.

В статье исследуются проблемы конституционного и законодательного процессов реформирования судебной власти и смежных институтов в Украине. Статья содержит анализ основных аспектов судебной реформы, включая изменения к Конституции Украины в части правосудия, и предлагает стратегическое видение путей развития судебной системы в Украине в соответствии с европейскими стандартами. Авторы высказывают мнения и приходят к выводам относительно предлагаемых конституционных изменений.

Ключевые слова: Конституция Украины, судебная власть, прокуратура, адвокатура, судебно-правовая реформа. 


\section{S u m m a r y}

Kivalov S. V., Poliansky Y.E., Dolezhan V.V., Bakayanova N.M., Svida O.G. Reforming the Judiciary and Related Judicial Institutions in Ukraine. - Article.

The article studies the problems of constitutional and legislative regulation of the process of reformation of the judiciary and related judicial institutions in Ukraine. The article includes the analysis of main aspects of the judicial reform, including the draft amendments to the Constitution of Ukraine with respect to justice, and offers a strategic vision of the ways to bring the judicial system of Ukraine into compliance with the European standards. The authors express their opinion and make suggestions regarding the proposed constitutional draft amendments.

Keywords: the Constitution of Ukraine, the judiciary, procuracy, advocacy, judicial reform 